\title{
Black Sea Observing System
}

\begin{abstract}
Atanas Palazov ${ }^{1 *}$, Stefania Ciliberti ${ }^{2}$, Elisaveta Peneva ${ }^{3}$, Marilaure Gregoire ${ }^{4}$, Joanna Staneva ${ }^{5}$, Benedicte Lemieux-Dudon ${ }^{2}$, Simona Masina ${ }^{2}$, Nadia Pinardi $^{6}$, Luc Vandenbulcke 4 , Arno Behrens ${ }^{5}$, Leonardo Lima ${ }^{2}$, Giovanni Coppini², Veselka Marinova ${ }^{1}$, Violeta Slabakova ${ }^{1}$, Rita Lecci ${ }^{2}$, Sergio Creti ${ }^{2}$, Francesco Palermo ${ }^{2}$, Laura Stefanizzi' ${ }^{2}$ Nadezhda Valcheva ${ }^{1}$ and Paola Agostini ${ }^{2}$
\end{abstract}

\begin{abstract}
${ }^{1}$ Institute of Oceanology, Bulgarian Academy of Sciences, Varna, Bulgaria, ${ }^{2}$ Euro-Mediterranean Center on Climate Change Foundation, Lecce, Italy, ${ }^{3}$ Faculty of Physics, Sofia University "St. Kliment Ohridski", Sofia, Bulgaria, ${ }^{4}$ Department of Astrophysics, Geophysics and Oceanography, University of Liège, Liège, Belgium, ${ }^{5} \mathrm{Helmholtz-Zentrum} \mathrm{Geesthacht,} \mathrm{Centre}$ for Materials and Coastal Research, Geesthacht, Germany, ${ }^{6}$ Department of Physics and Astronomy, University of Bologna, Bologna, Italy
\end{abstract}

OPEN ACCESS

Edited by:

Sanae Chiba,

Japan Agency for Marine-Earth

Science and Technology, Japan

Reviewed by:

Zhongping Lee,

University of Massachusetts Boston

United States

Katrin Schroeder,

Institute of Marine Sciences (ISMAR),

Georgios Sy

Italy

Democritus University of Thrace,

Greece

${ }^{*}$ Correspondence:

Atanas Palazov

palazov@io-bas.bg

Specialty section:

This article was submitted to

Ocean Observation,

a section of the journal

Frontiers in Marine Science

Received: 31 October 2018

Accepted: 27 May 2019

Published: 19 June 2019

Citation:

Palazov A, Ciliberti S, Peneva E,

Gregoire $M$, Staneva J,

Lemieux-Dudon B, Masina S,

Pinardi N, Vandenbulcke L, Behrens A, Lima L, Coppini G,

Marinova V, Slabakova V, Lecci $R$,

Creti S, Palermo F, Stefanizzi L,

Valcheva N and Agostini P (2019)

Black Sea Observing System.

Front. Mar. Sci. 6:315

doi: 10.3389/fmars.2019.00315
The ultimate goal of modern operational oceanography are end user oriented products with high scientific quality. Beneficiaries are the governmental services, coast and offshore based enterprises and research institutions that make use of the products generated by operational oceanography. Direct users are coastal managers, shipping, search and rescue, oil spill combat, offshore industry, ports, fishing, tourism, and recreation industry. Indirect beneficiaries, through climate forecasting based on ocean observations, are food, energy, water and medical suppliers. Availability of updated information on the actual state as well as forecast of marine environment is essential for the success and safety of maritime operations in the offshore industry. Various systems for the collection and presentation of marine data for the needs of different users have been developed and put in operation in the Black Sea. The systems are located both along the coast and in the open sea and the information they provide is used by both the maritime industry and the widest range of users. The Black Sea Monitoring and Forecasting Center in the frame of the Copernicus Marine Service is providing regular and systematic information about the physical state of the ocean, marine ecosystem and wave conditions in the Black Sea area, assimilating observations, keeping efficient operations, advanced technology and high quality modeling products. Combining and optimizing in situ, remote sensing, modeling and forecasting into a Black Sea observing system is a task that has to be solved, and that will allow to get a more complete and comprehensive picture of the state of the marine environment as well as to forecast future changes of physical and biogeochemical state of the Black Sea and the Black Sea ecosystem.

Keywords: Black Sea, observing system, operational oceanography, in situ measurements, modeling and forecasting, reanalyzes

\section{INTRODUCTION}

The Black Sea is one of the biggest semi enclosed sea basin on the Earth and have several specific features. It receives drainage from almost one-third of the continental Europe which includes 17 countries with about 160 million inhabitants. It is relatively isolated from the world ocean and has a limited exchange with the Mediterranean Sea through the Bosporus-Dardanelles Straits System. 
The fresh Black Sea water and salty water of Mediterranean origin inputs generate extremely strong vertical stratification, which prevents ventilation of the deepest part of the basin causing anoxia in the deep Black Sea. Several changes in the Black Sea ecosystem have been documented including a shift from a relatively pristine phase around 70-ies to a phase of ecosystem degradation till early 90-ies (Mee, 1992; Moncheva, 1995; Zaitsev and Alexandrov, 1997; Bodeanu et al., 1998; Shiganova, 1998; Daskalov, 2002; Kideys, 2002; Yunev et al., 2002, 2005). Monitoring and understanding the role of four-dimensional circulation and thermohaline structure on the biogeochemical processes are therefore a priority among different problems that need to be addressed. In fact, majority of in situ observations that are commonly used for monitoring are generally based on near-shore monitoring programs or irregular oceanographic cruises that provide either non-synoptic, coarse resolution realizations of large scale processes or detailed, but time and site specific snapshots of local features. A crucial element of the Black Sea restoration and rehabilitation initiatives is the implementation of a continuous monitoring and operational observing system in the region.

The aim of this study is to provide a comprehensive review of the observing, modeling, and forecasting activities that have been carried out till now in the Black Sea, to highlight the main gaps and disadvantages of existing observing and forecasting systems and to point out future initiatives to build a sustainable, high-performance and cost effective Black Sea observing system (BSOS), tailored to the end users' needs, integrated in European ocean observing system (EOOS) and providing the necessary information for sound management and sustainable development of the Black Sea basin in line with the United Nations Decade of Ocean Science for Sustainable Development (2021-2030).

\section{THE BLACK SEA OBSERVING AND FORECASTING SYSTEM (BSOS)}

The first two Black Sea GOOS EU projects FP5 ARENA (Slabakov et al., 2006) and FP6 ASCABOS (Slabakov et al., 2007; Palazov and Valchev, 2008) fulfilled their mission set out in the Black Sea GOOS Strategic Action and Implementation Plan (Kakhaber et al., 2003) and had fostered development of operational oceanography in the region. In the frame of ARENA a detailed evaluation of the observing systems as well as identification of gaps and needs have been performed and an integrated Black Sea near-real-time (NRT) operational oceanographic forecasting system to serve end users' needs have been designed.

In the frame of FP7 PERSEUS EU project, Poulain et al. (2013) reviewed observing systems in the Southern European Seas (Mediterranean and Black Seas) and concluded that: (1) Observations are carried out episodically and, therefore, no regular records are available; (2) Observations are part of focused research efforts and their results are not available at present for sharing with a wider community.

The most important findings of these three projects and recent additional studies gives the picture of the observing systems landscape in the Black Sea. Almost all nowadays available in situ data from Black Sea (Figure 1) are provided by copernicus marine environment monitoring service (CMEMS) INS-TAC ${ }^{1}$.

\section{In situ Component}

The number of operative coastal stations is about 85 but part of them is not equipped appropriately. While hydro-meteorological data are still collected, acquisition of biogeochemical data has been limited to an inappropriate level (Slabakov et al., 2006). POMOS - port operational marine observing system (Palazov et al., 2010) still provide real time information from coastal stations online ${ }^{2}$.

There are three fixed platforms on the Black Sea shelf. One is an oceanographic platform situated near the Southern coast of the Crimean settlement Katsiveli (Sizov et al., 2010) and used mainly for field researches. Another two are industrial platforms: Gloria in front of the Romania coast and Galata on the Bulgarian shelf (Palazov et al., 2007). An autonomous abovewater radiometer that is used for the continued assessment of the marine and atmospheric satellite products is installed on Gloria and Galata. The equipment is provided by JRC, Ispra and it is part of the international AERONET-OC system ${ }^{3}$ (Zibordi et al., 2006).

The marine part of the system developed in the frame of MARINEGEOHAZARD project (Ranguelov et al., 2011) includes five moorings: three in Romanian and two in Bulgarian waters. Each mooring consists of surface buoy and bottom tsunami meter. On the surface buoys a set of instruments is installed including: weather station, chlorophyll sensor, CTD, oxygen, turbidity, current, electronic compass and GPS receiver. Measured variables are transmitted from the moorings to data centers using satellite communication (Palazov et al., 2016b). Two surface buoys with bottom stations were deployed in Burgas and Varna bays (Bulgarian waters) in 2015. Several meteorological and oceanographic variables are provided by these moorings (Palazov et al., 2018).

Black Sea research institutions operates research vessels used to implement monitoring programs or scientific and commercial cruises (Slabakov et al., 2006; Palazov et al., 2015). Some of them periodically collect data from fixed stations according to national monitoring programs or EU directives but there is no coordination at regional level. Experience exists also with respect to ships-of-opportunity. However, the potential of regular ferry boat lines is not fully benefited. Therefore, suitable conditions for organization of an efficient FerryBOX program are at hand.

The Black Sea pilot drifter experiment has started in 1999 and continued during the period of 2001-2003 in framework of WMO-IOC's DBCP program. Totally 49 Lagrangian meteorological drifters were deployed from October 2001 to April 2003 (Slabakov et al., 2006). Another 16 drifters were launched in 2003 and 6 additionally equipped with temperature sensor - during March-April 2004.

The Black Sea Argo story began in September 2002 when 3 profiling floats were deployed (Korotaev et al., 2006). The NICOP

\footnotetext{
${ }^{1}$ http://marine.copernicus.eu/

${ }^{2}$ http://bgodc.io-bas.bg/ma/DefaultENG.aspx

${ }^{3}$ https://aeronet.gsfc.nasa.gov/new_web/ocean_color.html
} 


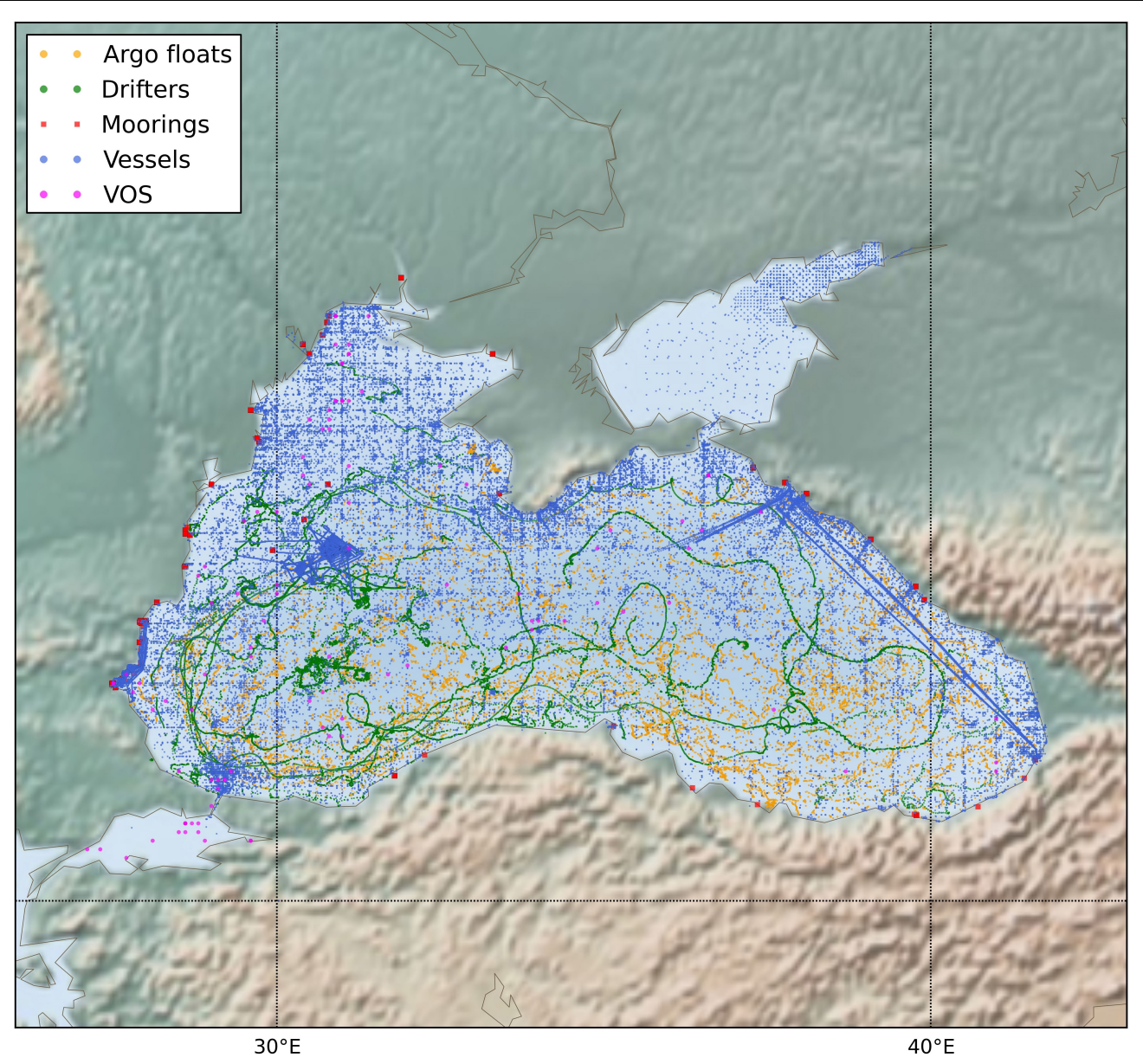

FIGURE 1 | Black Sea in situ data sources (1990-2018).

program led to deployment in total seven floats in the Black Sea within the period 2002-2006, but the quality of the data is not always high (Peneva et al., 2011). Other contributing programs are: HYPOX Project 2009 (Stanev et al., 2013) with two floats with DO sensors; EURO-ARGO with two floats (Peneva et al., 2011); BulArgo with four floats (Peneva et al., 2011; Palazov et al., 2012); DEKOSIM with four floats with DO sensors; MedARGO with six ARGO floats; E-AIMS with two biogeochemical floats and PERSEUS with three floats. In total 40 ARGO floats were deployed in the Black Sea (25 deployed by Bulgaria) till now (2002-2018) which provided more than 4000 CTD profiles. The Black Sea Argo experience shows that the average lifetime of the floats in Black Sea is about 36 months (Palazov et al., 2016a). The present-day number of Argo floats operating in the Black Sea of about 10, seems optimal for operational purposes (Grayek et al., 2015). According to the recommendations given by Poulain et al. (2009), the minimum population of five active floats is required for monitoring of the Black Sea.

\section{Remote Sensing}

Physical properties of the ocean such as sea surface temperature and slope, wave height and surface winds are currently measured globally at high resolution using satellites, providing information on the physical state of the ocean and reliable inputs to ocean circulation models. Similarly, ocean color measurements of phytoplankton pigment concentration are now used to monitor the marine ecosystem as well as to validate marine biogeochemical models. In particular, the most used are the remotely sensed measurements of sea surface temperature (SST), altimeter data (sea surface height, SSH), ocean color (OC) measurements (chlorophyll, water transparency, remote sensing reflectance) and sea surface salinity (SSS). The most important source of satellite data is the ESA Sentinel program.

\section{Modeling and Forecasting}

While the observing systems limit us to data on the past and present of the marine environment, modeling and forecasting allow us to have data on the future state of the sea. Thus models and forecasts become part of the observing system in wider context.

\section{ARENA, 2003-2006}

One of the major goal of ARENA project was to develop pilot nowcasting/forecasting system in the basin 
(Slabakov et al., 2006). The core basin-wide circulation model is the MHI NASU one that assimilates remote sensing data for the near-real time nowcasting and forecasting of three-dimensional fields of temperature, salinity and current (Dorofeev and Korotaev, 2004). The ecosystem module is based on the onedimensional bio-geochemical nitrogen cycle model (Oguz et al., 1999, 2001). Four regional models are nested to the basin-scale circulation model.

\section{ECOOP, 2007-2010}

The Black Sea coastal nowcasting and forecasting system (Kubryakov et al., 2012) was built within the framework of EU FP6 ECOOP project for five regions: the south-western basin along the coasts of Bulgaria and Turkey, the northwestern shelf along the Romanian and Ukrainian coasts, coastal zone around of the Crimea peninsula, the northeastern Russian coastal zone and the coastal zone of Georgia. The system operates in the realtime mode during the ECOOP project and afterward. Ecosystem model operates in the off-line mode near the Crimea coast.

\section{MyOcean, 2009-2015}

MyOcean's objective was to set up (definition, design, development and validation) an integrated Pan-European capability for ocean monitoring and forecasting, using nationally available skills and resources. The Black Sea coastal forecasting system forms a basis for the operations of the Black Sea Marine Forecasting Center build in the frame of the EU MyOcean project. The center provides the Basin-scale analysis and forecast product of the Black Sea circulation and stratification (temperature, salinity, currents, and sea level) as well as phytoplankton and nitrate concentration.

\section{CMEMS BS-MFC, 2016-2021}

Since 2016, the Black Sea monitoring and forecasting centre (BS-MFC) in the frame of CMEMS is providing regular and systematic information about the physical state of the ocean, marine ecosystem and wave conditions in the Black Sea area, keeping efficient operations, advanced technology and high quality modeling products (Palazov et al., 2017, 2018; Peneva et al., 2017; Ciliberti et al., 2018). To guarantee high quality products based on the scientific state-of-theart modeling frameworks and high operational reliability and robustness, the BS-MFC implements three Production Units, one for Physics, one for Biogeochemistry and one for Waves, fully connected to the CMEMS Dissemination Unit, in charge for products delivery, and supported by a Local Service Desk for supporting producers and CMEMS users on daily operations. The BS-MFC provides near real time and multiyear products for characterizing the Black Sea ocean dynamics, biogeochemical processes and wave conditions (Table 1). The modeling framework is built upon the stateof-the-art numerical models (NEMO ocean model for Physics, BAMHBI - BiogeochemicAl Model for Hypoixc and Benthic Influenced Areas (Grégoire et al., 2008; Grégoire and Soetaert, 2011; Capet et al., 2016) online coupled to GHER3D for Biogeochemistry (Grégoire et al., 2004, 2008; Vandenbulcke et al., 2010; Capet et al., 2016) and WAM - third generation spectral model for Waves (Wamdi Group, 1988; Komen et al., 1994; Staneva et al., 2015) and data assimilation techniques, able to carry on the impact and the evolution of the future observing network (Staneva et al., 2016; Wiese et al., 2018; Behrens et al., 2019). The BS-MFC provides information on essential ocean variables such as temperature, salinity, sea surface height, currents, concentration of chlorophyll, nutrients, dissolved oxygen, phytoplankton carbon biomass, and 2D field of vertically integrated net primary production and bottom oxygen concentration (for the shelf), significant wave height, the mean wave period, the mean wave direction, the Stokes drift, the wind wave, the primary swell wave and the secondary swell wave. Furthermore, the BS-MFC contributes to the annual Ocean State Report (von Schuckmann et al., 2018), which is becoming the European scientific reference aiming to provide a comprehensive and state-of-the art assessment of the current state, natural variations, and changes in the global ocean and European regional seas, including the Black Sea. It is meant to act as a reference document for the ocean scientific community, business community, policy and decision-makers as well as the general public. Finally, BS-MFC contributes to the delivering of Ocean Monitoring Indicators (OMI, 2018).

\section{BSOS CONNECTIONS WITH OTHER OBSERVING SYSTEMS/PROGRAMS}

\section{Copernicus}

Nowadays Copernicus EU program has a valuable contribution to the BSOS. CMEMS BS-MFC is providing both basin scale NRT and multiyear products while BSOS is providing in situ data for the need of INS-TAC of CMEMS.

\section{EMODNet}

Black Sea is presented in all seven EMODNet thematic portals. Black Sea checkpoint is a wide monitoring system assessment activity aiming to support the sustainable Blue Growth at the scale of the European Black Sea by clarifying the observation landscape, evaluating the fitness for use of current observations and data assembly programs toward targeted applications (challenges) and prioritizing the needs to optimize monitoring systems in terms of availability, operational reliability, efficiency, time consistency, space consistency, etc.

\section{WHY DO WE NEED A LONG-TERM BLACK SEA OBSERVING SYSTEM?}

The review of the existing Black Sea observing systems made above shows a number of shortcomings and gaps in terms of observed parameters, spatial and temporal distribution of data (Lyubartse et al., 2018), non-harmonization of individual systems, lack of standardization, lack of regular data exchange and insufficient regional cooperation. Reference in situ data are also mandatory for regional satellite products validation and calibration. To improve near real time system skill scores 
and multiyear products quality of Physics, Biogeochemistry and Wave systems, a robust observing network is fundamental. Currently, the lack of independent data represents a limit for hydrodynamic core model validation, especially in shallow areas where quality checked and consistent near real time data is insufficient. The lack of data applies as well for in situ wave measurements: mooring buoy stations distributed along the coastal area are extremely insufficient and not continuous in time. To drive the new scientific challenges for the development of the Black Sea operational systems, it is necessary to define also new technological opportunities for improving both satellite and in situ infrastructures, able to support the R\&D activities such as the modeling and assimilation capabilities, validation and verification of modeling and satellite products, real time monitoring, estimation of quality of physical variables (e.g., mixed layer depth, stratification, cold intermediate layer content). The future plans for improving the quality of modeling products and their accuracy in the Black Sea require a considerable investment in empowering the observing system network toward the coastal areas as well as a reliable modeling framework able to account new observations and evaluate the impact on error characterization.

\section{Scientific Questions}

The following subset of scientific questions outlines the essential motivation for the Black Sea observing system: (1) What long-term trends can be observed in the physical and biogeochemical state of the Black Sea? (2) What is the current state of the Black Sea and could one identify regime shifts? (3) What is the Black Sea system variability ranging from mesoscale, seasonal, interannual to decadal time scales? How does the sea respond to the global atmospheric forcing and how the climate influence propagates from surface to deep layers? (4) Which mechanisms control the vertical water mass transformation and the position of the thermocline, halocline and oxycline? (5) What is the impact of the Bosporus and Kerch Strait flows on the physical and biogeochemical processes? (6) What is the role of the Black Sea in the regional climate change? (7) What are the level of anthropogenic stressors in terms of nutrient loads, atmosphere heating, deoxygenation, acidification etc., which still conserve the ecosystem health?

\section{Society Challenges}

The analysis of information received during the extensive inquiry among all potential end users (Slabakov et al., 2006) reveals variety of data and information needs encompassing physical, chemical, and biological observation. Several classes of users of BSOS data and products are specified such as: shipping, offshore oil and gas industry, ports, coastal tourism and recreation, fishing and aquaculture, coastal managers, civil protection, oil spills combat, search and rescue, environmental protection etc. The common requirement concerns development of forecasting system providing accurate real-time or near-real time information assisting decision making and environmental management.

\section{Fill Gaps and Needs}

Some of these issues of concern and gaps are the following:

- Lack of real time oceanographic data;

- Poor geographical coverage;

- Lack of modern instruments and sensors;

- Lack or sparse monitoring of biogeochemical parameters, waves and currents;

- Need for homogenization of data management.

TABLE 1 | CMEMS BS-MFC operational products.

\begin{tabular}{|c|c|c|c|}
\hline & BS-PHY & BS-BIO & BS-WAV \\
\hline Variables & $\begin{array}{l}\text { 3D temperature, salinity, currents, sea } \\
\text { surface height, bottom temperature, mixed } \\
\text { layer depth }\end{array}$ & $\begin{array}{l}\text { 3D concentration of chlorophyll, nutrients } \\
\text { (nitrate and phosphate), dissolved oxygen, } \\
\text { phytoplankton carbon biomass, and 2D } \\
\text { field of vertically integrated net primary } \\
\text { production and bottom oxygen } \\
\text { concentration (for the shelf) }\end{array}$ & $\begin{array}{l}\text { Most relevant wave parameters and } \\
\text { variables, such as the } 2 \text { D significant wave } \\
\text { height, the mean wave period, the mean } \\
\text { wave direction, the Stokes drift, the wind } \\
\text { wave, the primary swell wave and the } \\
\text { secondary swell wave. }\end{array}$ \\
\hline \multirow[t]{2}{*}{ Temporal resolution } & NRT: Daily/Hourly means & NRT: Daily means & NRT: Hourly instantaneous \\
\hline & MYP: Monthly/Daily means & MYP: Monthly/Daily means & MYP: Hourly instantaneous \\
\hline \multirow[t]{2}{*}{ Available time series } & NRT: from 2016-ongoing & NRT: from 2016-ongoing & NRT: from 2016-ongoing \\
\hline & MYP: January 1992 - December 2017 & MYP: January 1992 - December 2017 & MYP: January 2002 - December 2017 \\
\hline \multirow{2}{*}{$\begin{array}{l}\text { Product name in } \\
\text { CMEMS Catalog }\end{array}$} & NRT: PHYS_007_001 & NRT: BIO_007_008 & NRT: WAV_007_003 \\
\hline & MYP: PHYS_007_004 & MYP: BIO_007_005 & MYP: WAV_007_006 \\
\hline $\begin{array}{l}\text { Description of the } \\
\text { model setup }\end{array}$ & $\begin{array}{l}\text { NEMO, } 1 / 27^{\circ} \times 1 / 36^{\circ}, 31 \text { levels, TKE } \\
\text { vertical mixing scheme ECMWF } \\
\text { atmospheric forcing Assimilation of ARGO } \\
\text { T,S profiles, SLA and SST using 3DVAR } \\
\text { scheme Main rivers as climatological } \\
\text { means, the Bosporus as SBC }\end{array}$ & $\begin{array}{l}\text { BAMHBI system online coupled with } \\
\text { GHER3D, } 1 / 22^{\circ} \text { res., } 31 \text { levels Assimilation } \\
\text { of ARGO oxygen data using SEEK filter } \\
\text { ECMWF atmospheric forcing Major rivers } \\
\text { (and the Bosporus as an open sea } \\
\text { boundary condition) }\end{array}$ & $\begin{array}{l}\text { Black Sea Wave model based on WAM, } \\
1 / 27^{\circ} \times 1 / 36^{\circ} \text { wave spectra discretization: } \\
30 \text { frequency and } 24 \text { directional bins } \\
\text { ECMWF atmospheric forcing Assimilation of } \\
\text { SWH from satellite using optimal } \\
\text { interpolation }\end{array}$ \\
\hline
\end{tabular}

NRT, near real-time; MYP, multi year product. 


\section{RECOMMENDATIONS FOR A SUSTAINED BSOS}

As a potentially integrated part of EOOS, BSOS should be a system of monitoring and forecasting systems, providing essential ocean variables (EOV) from days to decades and from shore to the high seas, responding to the needs of science and society, contributing to the quality of life and the well-being of citizens, supports the sustainable use of Black Sea resource and contributes to the challenges of climate change (Tintoré et al., 2015b). It should be built on well-defined and generally accepted principles, in particular related to the issues of multi-platform observing, technological development, physical and biogeochemical data and connectivity, sustainability, free availability of data and support for the next generation of ocean scientists. The principles as outlined in the Strategy vision document (Tintoré et al., 2015a) should guide the development, decision making and interaction with BSOS partners, users and other collaborating institutions.

Existing observing systems should be upgraded with new sensors and technologies as a focus should be on biosensors. Antifouling technologies should be implemented to secure long term observations using optical sensors. Application of wave riders to provide data needed for assimilation in the wave models and verification of the wave forecasts is considered as important. HF radars as an effective instrument for coastal researches are strongly recommended. Integration of existing observing systems delivering in situ data, remote sensing data, modeling and forecasting toward delivering products for science, marine industry and society is an approach without alternative.

There must be an effort during the upcoming period toward an effective basin scale and EU cooperation and coordination between agencies and research institutes in order to establish a more homogeneous management of the observing systems,

\section{REFERENCES}

Behrens, A., Staneva, J., and Geyer, G. (2019). Verification of a high resolution operational wave model in the data sparse Black Sea. J. Operat. Oceanogr. (in press).

Bodeanu, N., Moncheva, S., Ruta, G., and Popa, L. (1998). Long-term evolution of the algal blooms in Romanian and Bulgarian Black Sea waters. Cercetari Mar. 31, 37-55.

Capet, A., Meysman, F. J. R., Akoumianaki, I., and Soetaert, K. (2016). Integrating sediment biogeochemistry into 3D oceanic models: a study of benthic-pelagic coupling in the Black Sea. Ocean Model. 101, 83-100. doi: 10.1016/j.ocemod. 2016.03.006

Ciliberti, S., Atanas, P., Marilaure, G., Joanna, S., Elisaveta, P., and Benedicte, L. D. (2018). "The copernicus marine service for the Black Sea: products for user needs, modelling challenges and future perspectives," in Proceedings of the European Ocean Observing System Conference EOOS, (Brussels).

Daskalov, G. M. (2002). Overfishing drives a trophic cascade in the Black Sea. Mar. Ecol. Prog. Ser. 225, 53-63. doi: 10.3354/meps 225053

Dorofeev, V., and Korotaev, G. (2004). Assimilation of the satellite altimetry data in the eddy-resolving model of the Black Sea circulation. Mar. Hydrophys. J. 1, 52-68. and they to begin to apply the same best management practice, uniform quality standards and common vocabularies. Each operator must be encouraged to submit all necessary information in pan European directories and databases, keep track of changes and update regularly. Data management recommendations must be circulated to operators and validation-calibration procedures must be established in a more comprehensive way. Support new buoy deployments emphasizing in offshore locations of important transitional areas where timeseries will boost research studies and operational work. Emphasis must also be given in integrating biochemical sensors as time series moorings are at present the only method/technology to provide a complete long term suite of biogeochemical variables, such as chlorophyll, oxygen, $\mathrm{CO}_{2}$, and nutrients. These data are essential for validation and assessment purposes. Operators must keep track of new sensor technologies and propose new fields of research and monitoring such as environmental studies, marine litter, marine noise etc.

\section{AUTHOR CONTRIBUTIONS}

All authors listed have made a substantial, direct and intellectual contribution to the work, and approved it for publication. In particular AP as the lead author, coordinated the drafting and wrote the major part of the review. SC is the lead author of modeling and forecasting activities in particular CMEMS BSMFC part and wrote this part with the contributions of EP, MG, JS, BLD, SM, NP, LV, AB, LL, GC, RL, SC, FP, LS, NV, and PA. VM and VS contributed to introduction, in situ and remote sensing components description. EP and NP contributed to analysis of scientific questions, gaps and needs. EP, JS, MG, VM and VS helped to improve the manuscript during the review process. AP has taken primary responsibility for communication with the journal and editorial office during the submission process, throughout peer review and during publication.

Grayek, S., Emil Stanev, V., and Johannes, S. S. (2015). Assessment of the Black Sea observing system. A focus on 2005-2012 Argo campaigns. Ocean Dyn. 65, 1665-1684. doi: 10.1007/s10236-0150889-8

Grégoire, M., Raick, C., and Soetaert, K. (2008). Numerical modelling of the central black sea ecosystem functioning during the eutrophication phase. Prog. Oceanogr. 76, 286-333. doi: 10.1016/j.pocean.2008. 01.002

Grégoire, M., and Soetaert, K. (2011). Carbon, nitrogen, oxygen and sulfide budgets in the Black Sea: a biogeochemical model of the whole water column coupling the oxic and anoxic parts. Ecol. Model. 15, 2287-2301. doi: 10.1016/j.ecolmodel. 2010.06.007

Grégoire, M., Soetaert, K., Nezlin, N. P., and Kostianoy, A. G. (2004). Modellingthe nitrogen cycling and plankton productivity in the Black Sea using a threedimensional interdisciplinary model. J. Geophys. Res. Oceans 109:C05007. doi: 10.1029/2001JC001014

Kakhaber, B., Cordoneanu, E., Gennady, K., and Kubryakov, A. I. (2003). Black Sea GOOS Strategic Action and Implementation Plan. Goos Report, 133 (IOC/INF1176). Paris: UNESCO.

Kideys, A. (2002). “The comb jelly Mneniopsis leidyi in the Black Sea," in Invasive Aquatic Species of Europe: Distribution, Impacts and Management, ed. E. 
Leppäkoski (Dordrecht: Kluwer Academic), 56-61. doi: 10.1007/978-94-0159956-6_6

Komen, G. J., Cavaleri, L., and Donelan, M. (1994). Dynamics and Modelling of Ocean Waves. Cambridge: Cambridge university press.

Korotaev, G., Oguz, T., and Riser, S. (2006). Intermediate and deep currents of the Black Sea obtained from autonomous profiling floats. Deep Sea Res. II 53, 1901-1910. doi: 10.1016/j.dsr2.2006.04.017

Kubryakov, A. I., Korotaev, G. K., Dorofeev, V. L., Ratner, Y. B., Palazov, A., Valchev, N., et al. (2012). Black Sea coastal forecasting system. Ocean Sci. 8, 183-196. doi: 10.5194/os-8-183-2012

Lyubartse, V., Nadia, P., Atanas, P., Violeta, S., Luminita, B., Frederique, B., et al. (2018). Black Sea Checkpoint Second Data Adequacy Report. Available at: http://emodnet-blacksea.eu/wp-content/uploads/2018/04/D15.4_ DAR2_v7_FINAL.pdf (accessed October 30, 2018).

Mee, L. D. (1992). The Black Sea in Crisis: a need for concerted international action. Ambio 21, 278-286.

Moncheva, S. (1995). "Phytoplankton under the influence of eutrophication peculiarities and ecological significance," in Proceedings of the Symposium on "Ecological Problems and Economical Prospects of the Black sea", (Istanbul: Black Sea Foundation), 271-279.

Oguz, T., Ducklow, H., Malanotte-Rizzoli, P., Murray, J. W., Vedernikov, V., and Unluata, U. (1999). A physical-biochemical model of plankton productivity and nitrogen cycling in the Black Sea. Deep Sea Res., I 46, 597-636. doi: 10.1016/s0967-0637(98)00074-0

Oguz, T., Murray, J. W., and Callahan, A. (2001). Simulation of suboxic-anoxic interface zone structure in the Black Sea. Deep Sea Res. I 48, 761-787. doi: 10.1016/s0967-0637(00)00054-6

OMI (2018). Ocean Monitoring Indicators. Available at: http://marine.copernicus. eu/science-learning/ocean-monitoring-indicators/ (accessed October 30, 2018).

Palazov, A., Giovanni, C., Stefania, A. C., Marilaure, G., Joanna, S., and Elisaveta, P. (2017). The Black Sea monitoring and forecasting center (bs-mfc) in the framework of the copernicus marine service. Geophys. Res. Abstr. 19, EGU2017EGU15637.

Palazov, A., Violeta, S., and Veselka, M. (2018). "New sources of in-situ marine data to support EC marine strategy framework directive implementation in the black sea, in operational oceanography serving sustainable marine development," in Proceedings of the 8th EuroGOOS International Conference. eds E. Buch, V. Fernández, D. Eparkhina, P. Gorringe, and G. Nolan (Bergen: EuroGOOS), 89-96.

Palazov, A., Slabakov, H., and Stefanov, A. (2007). "Galata platform weather and seastate observing system," in Marine Industry, Ocean Engineering and Coastal Resources. eds G. Soares and P. N. Kolev (London: Taylor \& Francis Group), 755-760.

Palazov, A., Slabakova, V., Peneva, E., Staefanov, A., Marinova, V., Milanova, M., et al. (2012). "BULARGO activities in the Black Sea," in Proceedings of the TU-Varna International Jubilee Congress. (Varna), 110-115.

Palazov, A., Slabakova, V., Peneva, E., and Stanev, E. (2016a). "Black Sea Argo history, current status and prospect, operational oceanography for sustainable blue growth," in Proceedings of the 7th EuroGOOS International Conference, eds E. Buch, Y. Antoniou, D. Eparkhina, and G. Nolan (Lisbon: EuroGOOS AISBL), 519-526.

Palazov, A., Stefanov, A., Marinova, V., and Slabakova, V. (2016b). "Operational oceanography products and services for maritime industry, operational oceanography for sustainable blue growth," in Proceedings of the 7th EuroGOOS International Conference. eds E. Buch, Y. Antoniou, D. Eparkhina, and G. Nolan (Brussels: EuroGOOS AISBL), 145-156.

Palazov, A., Stefanov, A., Marinova, V., and Slabakova, V. (2010). "Operational marine observing system to support safety port navigation", in Proceedings of the Tenth International Conference on Marine Sciences and Technologies "Black Sea 2010" (Varna: Bulgaria), 308-312.

Palazov, A., Stanchev, H., and Valcheva, N. (2015). "Bulgarian Black Sea Monitoring Programme 2015," in Proceedings of 12th International Conference on the Mediterranean Coastal Environment - MEDCOAST. (Varna).

Palazov, A., and Valchev, N. (2008). "Advance in the Black Sea regional efforts to build and sustain the operational status of oceanographic services," in Proceedings of EuroGOOS Conference 2008, Coastal to
Global Operational Oceanography: Achievements and Challenges, (Exeter), 380-387.

Peneva, E., Emil, S., and Atanas, P. (2017). "The new copernicus black sea monitoring and forecasting centre: towards black sea operational oceanography," in Proceedings of the 3rd National Congress on Physical Sciences. (Sofia).

Peneva, E., Stanev, E., Palazov, A., Korchev, G., Slabakova, V., Milanova, M., et al. (2011). "BULARGO national research infrastructure: the present state and perspectives for the Argo data in the Black Sea," in Proceedings of the 10th International Conference on Marine Sciences and Technologies "Black Sea 2010". (Bulgaria), 318-323.

Poulain, P. M., Solari, M., Notarstefano, G., and Rupolo, V. (2009). Assessment of the Argo Sampling in the Mediterranean and Black Seas (part II). OGS Technical Report OGS 2009/139. OGA: Trieste: 1-23.

Poulain, P.-M., Tintoré, J., Heslop, E., Manzella, G., Schroeder, K., Kassis, D., et al. (2013). Review of Ocean Observing Systems in the SES and Recommendations on Upgrades to Serve PERSEUS Needs. New York, NY: PERSEUS.

Ranguelov, B., Radichev, R., Dimovsky, S., Oaie, G., Dimitriu, R., Diaconescu, M., et al. (2011). MARINEGEOHAZARDS project - key core elements of the early warning sysyem in the Black Sea. Geol. Geophys. 54, $177-182$.

Shiganova, T. A. (1998). Invasion of the Black Sea by the ctenophore Mnemiopsisleidyi and recent changes in pelagic community structure. Fish. Oceanogr. 7, 305-310. doi: 10.1046/j.1365-2419.1998.00080.x

Sizov, A. A., Kuznetsov, A. C., Polonski, A. B., and Spichak, N. I. (2010). "History of the creation and operation of the stationary oceanographic platform in Katsiveli (on the 30th anniversary)." in Ecological Safety of the Coastal and Shelf Zones and the Integrated use of Shelf Resources. Vol. 21, (Russian), 69-73.

Slabakov, H., Palazov, A., Besiktepe, S., Korotaev, G., Nikolaev, S., and Bilashvili, K. (2006). "Recent advance in the black sea operational oceanography within the arena project," in Proceedings of the 1st Biannual Scientific Conference "Black Sea Ecosystem 2005 and Beyond". (Istanbul), 1229-1244.

Slabakov, H., Palazov, A., and Valchev, N. (2007). ASCABOS - a new capacity building programme supporting oceanographic services in the Black Sea. Rapp. Comm. Int. Mer Médit. 38:199.

Stanev, E., He, Y., Grayek, S., and Boetius, A. (2013). Oxygen dynamics in the Black Sea as seen by Argo profiling floats. Geophys. Res. Lett. 40, 3085-3090. doi: 10.1002/grl.50606

Staneva, J., Behrens, A., and Wahle, K. (2015). Wave modelling for the coastalocean predicting system. J. Phys. 633, 233-254.

Staneva, J., Wahle, K., Koch, W., Behrens, A., Fenoglio-Marc, L., and Stanev, E. (2016). Coastal flooding: impact of waves on storm surge during extremes. Nat. Hazards Earth Syst. Sci. 16, 2373-2389. doi: 10.5194/nhess-16-23732016S

Tintoré, J., Leonidas, P., and Heslop, E. (2015a). "Strategy for an integrated ocean observing system in the mediterranean and Black Seas," in Proceedings of the Kostas Nittis Scientific and Strategic Workshop. (Athens).

Tintoré, J., Perivoliotis, L., Heslop, E. E., Poulain, P.-M., Crise, A., and Mortier, L. (2015b). Recommendations for European long term sustained observations in the SES. New York, NY: PERSEUS Project.

Vandenbulcke, L., Beckers, J. M., Capet, A., Grégoire, M., and Besiktepe, S. (2010). Onboard Implementation of the GHER M odel for the Black Sea, with SST and CTD Data Assimilation. J. Operat. Oceanogr. 3, 47-54. doi: 10.1080/1755876X. 2010.11020117

von Schuckmann, K., Pierre-Yves, L. T., Neville, S., Ananda, P., Pierre, B., Katja, F., et al. (2018). Copernicus marine service ocean state report. J. Operat. Oceanogr. 11(Suppl. 1), S1-S142. doi: 10.1080/1755876X.2018.1489208

Wamdi Group. (1988). The WAM model - a third generation ocean wave prediction model. J. Phys. Oceanogr. 18, 1775-1810. doi: 10.1175/15200485(1988)018<1775:twmtgo $>2.0 . c 0 ; 2$

Wiese, A., Staneva, J., Schultz-Stellenfleth, J., Behrens, A., Fenoglio-Marc, L., and Bidlot, J. R. (2018). Synergy between satellite observations and model simulations during extreme events. Ocean Sci. 14, $1503-1521$.

Yunev, O., Moncheva, S., and Carstensen, J. (2005). Long-term variability of vertical chlorophyll a and nitrate profiles in the open Black Sea: eutrophication and climate change. Mar. Ecol. Prog. Ser. 294, 95-99. 
Yunev, O. A., Vedernikov, V. I., Basturk, O., Yilmaz, A., Kideys, A. E., Moncheva, S., et al. (2002). Long-term variations in surface chlorophylla and primary production in the open Black Sea: changes in the pelagic ecosystem over the last decades. Mar. Ecol. Prog. Ser. 230, 11-28. doi: 10.3354/ meps 230011

Zaitsev, Y. P., and Alexandrov, B. G. (1997). "Recent man-made changes in the Black Sea ecosystem," in Sensitivity to Change: Black Sea, Baltic Sea and North Sea, eds E. Ozsoy and A. Mikaelyan (Dordrecht: Kluwer Academic Publishing), 25-31. doi: 10.1007/978-94-011-5758-2_3

Zibordi, G., Holben, B., Hooker, S. B., Mélin, F., Berthon, J. F., Slutsker, I., et al. (2006). A network for standardized ocean color validation measurements. Eos., $87,293-297$.
Conflict of Interest Statement: The authors declare that the research was conducted in the absence of any commercial or financial relationships that could be construed as a potential conflict of interest.

Copyright (c) 2019 Palazov, Ciliberti, Peneva, Gregoire, Staneva, Lemieux-Dudon, Masina, Pinardi, Vandenbulcke, Behrens, Lima, Coppini, Marinova, Slabakova, Lecci, Creti, Palermo, Stefanizzi, Valcheva and Agostini. This is an open-access article distributed under the terms of the Creative Commons Attribution License (CC BY). The use, distribution or reproduction in other forums is permitted, provided the original author(s) and the copyright owner(s) are credited and that the original publication in this journal is cited, in accordance with accepted academic practice. No use, distribution or reproduction is permitted which does not comply with these terms. 